\title{
Phylloceratina ammonoids in the Iberian Basin during the Middle Jurassic: a model of biogeographical and taphonomic dispersal related to relative sea-level changes
}

\author{
S. Fernández-López ${ }^{\mathrm{a}}, \mathrm{G}$. Meléndez ${ }^{\mathrm{b}}$ \\ ${ }^{a}$ Departamento de Paleontología, Facultad de Ciencias Geológicas (UCM) e Instituto de Geología Económica \\ (CSIC-UCM), 28040 Madrid, Spain \\ ${ }^{b}$ Area de Paleontología, De partamento de Ciencias de la Tierra, Facultad de Ciencias, Universidad de Zaragoza, \\ 50009 Zaragoza, Spain
}

\begin{abstract}
Phylloceratina and Lytoceratina ammonoids in the Middle Jurassic of the Iberian Chain (E. Spain) represent less than $1 \%$ of the whole of Ammonoidea. There are two intervals, however, in which their occurrence is remarkably constant: within the Upper Bajocian and at the Lower/Middle Callovian boundary. These two dispersal episodes of Phylloceratina and Lytoceratina into the Iberian Basin are regarded to reflect changes in their palaeoecological and taphonomical behaviour, as a consequence of regional sea-level changes during the Middle Jurassic. A relative rise during the Late Bajocian favoured the immigration of juvenile phyllocerataceans. Phylloceras and Adabofoloceras immigrations gave rise to monospecific assemblages, where they soon died. They did not breed or ontogenically develop in this basin. In contrast, phyllocerataceans recorded at the Lower/Middle Callovian boundary constitute polyspecific assemblages, dominated by adult individuals. These Callovian assemblages were formed by nekroplanktonic drift, related to a relative sea-level fall and general homogenization of the shelf bottom, hence favouring the concentration of remains of organisms from more open marine and oceanic areas.
\end{abstract}

\section{Introduction}

Ammonites of the suborder Phylloceratina have raditionally been considered as absent from the palaeontological record in the Middle Jurassic of the Iberian Chain (Neumayr, 1885 fide Dereims, 1898; Haug, 1908; Bataller, 1922; Elmi, 1985; Sequeiros, 1987; Thierry and Wilde, 1990). However, some remains of Phylloceratina and Lytoceratina are in fact present and appear to be relatively constant at some stratigraphic intervals in the Middle Jurassic. Shells of these ammonoids, classically considered as characteristic inhabitants of oceanic environments, are more abundant and geographically persistent within the Upper Bajocian sediments and at the Lower-Middle Callovian boundary. The purpose of this paper is to show that the distribution of Phylloceratina shells in the Iberian Basin during these two episodes was mainly controlled by relative changes of sea level, favouring their biogeographical and taphonomic dispersal. 


\section{Distribution of Phylloceratina and Lytoceratina} in the Middle Jurassic of the Iberian Chain

Representatives of superfamilies Phyllocerataceae and Lytocerataceae have been reported by several authors in the Middle Jurassic of the Iberian Chain. Eighty specimens of Phylloceratina have been so far reported from the Aalenian, Bajocian, Bathonian and Callovian, in sixteen localities of the Iberian Chain (Fig. 1). All these specimens, though, represent less than $1 \%$ of the whole of Ammonoidea in the fossil assemblages.

Some specimens of the genus Phylloceras have been reported from the Lower Bajocian of Villel (Sauzei and Humphriesianum zones, Hinkelbein, 1975), and from the Upper Bajocian of Tivenys (Niortense and Garantiana Zones, Fallot and Blanchet, 1923; Fernández-López, 1983; Fernández-López and Mouterde, 1985), Hontoria (Westermann, 1955), Ricla (Mensink, 1966), Tuejar, Riodeva and Albarracin (Niortense and Garantiana Zones, Hinkelbein, 1975), Ribarroja and Rambla La Gotera (Niortense Zone, Fernández-López, 1980), as well as from the Callovian of Frias de Albarracin (Riba Arderiu, 1959), Tuejar, Riodeva, Villel (Hinkelbein, 1975) and Ricla (Sequeiros and Cariou, 1985). A Callovian specimen of Phylloceras kudernatschi (Hauer) is also reported here. The only record so far reported from the Aalenian is a large size

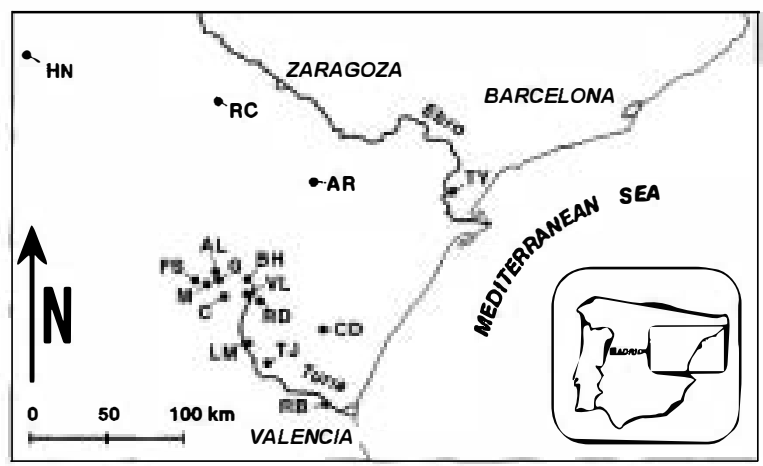

Fig. 1. Geographical location of the referred outcrops $(A L=$ Albarracin, $A R=$ Ariño, $B H=$ San Blas dam, $\mathrm{C}=\mathrm{La}$ Canaleja cliff, $\mathrm{CD}=$ Caudiel, $F S=$ Frías de Albarracín, $G=$ Rambla La Gotera, $H N=$ Hontoria,$L M=\mathrm{La}$ Olmeda, $\mathrm{M}=$ Moscardón, $R B=$ Ribarroja,$\quad R C=$ Ricla,$\quad R D=$ Riodeva,$\quad T J=$ Tuejar, $T Y=$ Tivenys, $V L=$ Villel).
$(140 \mathrm{~mm})$ incomplete phragmocone from the Lower Aalenian, Opalinum Zone, of Ariño. Callovian shells are also large-sized, some of them over $150 \mathrm{~mm}$ diameter. In contrast, Bajocian specimens are mostly millimetric in size, showing a corroded suture line, and it cannot be excluded that they belong to the genus Adabofoloceras.

Several Lower Bajocian representatives of Adabofoloceras have been identified in La Olmeda and Barranco La Canaleja (Humphriesianum Zone, Fernández-López, 1985c) and they are also common in the Upper Bajocian from Tivenys, Ribarroja and Barranco La Canaleja (Niortense and Garantiana Zones, Fernández-López, 1980, 1983, 1985c).

Some representatives of Calliphylloceras come from the Upper Bajocian of Albarracin (Niortense Zone, Hinkelbein, 1975) and Ricla (Garantiana Zone, Fernández-López and Aurell, 1988). However, specimens of Calliphylloceras appear more common and constant in the Callovian sediments, as regards the number of specimens reported from the Ariño region (Marin and Toulouse, 1972); Tuejar, Riodeva and Villel (Hinkelbein, 1975), Moscardón and Frías de Albarracín (Fernández-López et al., 1978). The species C. disputabile (Zittel) is the most abundant among the Callovian associations.

Some references to Holcophylloceras have been reported from the Lower Bajocian of Albarracin (Sauzei Zone, Hinkelbein, 1975) and from the Upper Bajocian of Tivenys and Ricla (Garantiana Zone, Fernández-López, 1983; Fernández-López and Mouterde, 1985, Fernández-López and Aurell, 1988). However, representatives of this genus are more common at the Lower-Middle Callovian boundary. They have been recognized at the region of Ariño (Marin and Toulouse, 1972), Tuejar and Villel (Hinkelbein, 1975), Caudiel, Moscardón and Frías de Albarracín (Fernández-López et al., 1978; Fernández-López, 1985a).

Representatives of Ptychophylloceras are very scarce. However, they have been recognized in the Upper Bajocian of Villel and Ribarroja (Garantiana Zone, Hinkelbein, 1975, and Niortense Zone, Fernández-López, 1980). A few Callovian specimens of this genus are known from 
Tuejar and Villel (Hinkelbein, 1975) and from Moscardón.

No specimens from the genus Sowerbyceras have been reported so far from the Middle Jurassic of the Iberian Chain. Some recorded specimens, e.g. at the localities of Tuejar and Moscardón, come from the iron oolite level at the CallovianOxfordian boundary, with some other elements from the Middle and Upper Jurassic. They are a part of condensed associations containing reworked (reelaborated sensu Fernández-López, 1985a, 1991; Fernández López and Meléndez, 1994) Callovian specimens mixed with resedimented Oxfordian specimens (Hinkelbein, 1975; Sequeiros et al., 1985; Meléndez, 1989), and are probably Oxfordian in age.

Some adult specimens of Lytoceras have been found in several localities and stratigraphic intervals: Lower Bajocian of Ribarroja (Humphriesianum Zone, Fernández-López, 1980), Upper Bajocian of San Blas (Niortense Zone, Fernández-López, 1985c), Lower Bathonian of Ricla (Fernández-López and Aurell, 1988), and Callovian of Riodeva, Villel, Moscardón, Frías de Albarracín and Ricla (Hinkelbein, 1975; Fernández-López et al., 1978, Sequeiros and Cariou, 1985). One specimen of Nannolytoceras cf. polyhelictum (Boeckh) comes from the Upper Bajocian of San Blas (Niortense Zone, FernándezLópez, 1985c).

In the Middle Jurassic of the Iberian Chain, phyllocerataceans $(87,1 \%)$ are far more common than lytocerataceans $(12,9 \%)$. They correspond, in decreasing order of abundance (Fig. 2), to the following genera: Phylloceras (30.8\%), Calliphylloceras (17.9\%), Holcophylloceras (17.9\%), Adabofoloceras (12.8\%), Lytoceras (11.6\%), Ptychophylloceras (7.7\%), and Nannolytoceras $(1.3 \%)$.

Despite their scarcity, shells of Phylloceratina and Lytoceratina show their highest frequency (Fig. 3) at the Lower-Middle Callovian boundary level $(51.3 \%)$ and in the Upper Bajocian $(37.2 \%$; Niortense Zone, Baculata Biohorizon, and Garantiana Zone). These two Middle Jurassic intervals also show the highest concentration of Ammonitina in the Iberian Chain. The virtual absence of phylloceratids and lytoceratids in the

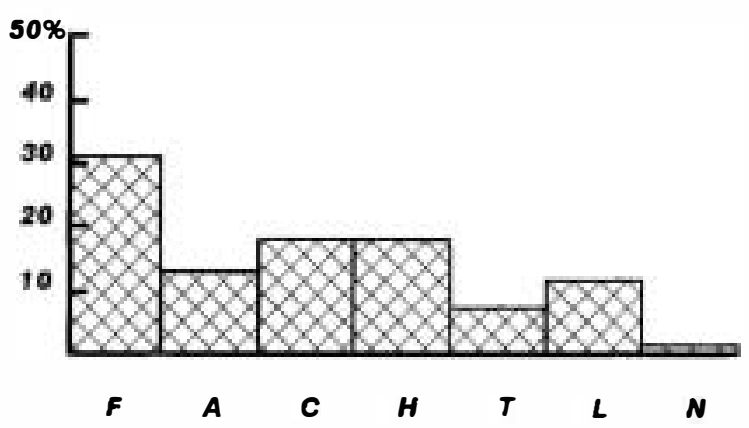

Fig. 2. Relative frequencies, at a generic level, of Phylloceratina and Lytoceratina recorded from the Middle Jurassic of the Iberian Chain $(F=$ Phylloceras, $A=$ Adabofoloceras, $C=$ Calliphylloceras, $\mathrm{H}=$ Holcophylloceras, $T=$ Ptychophylloceras, $L=$ Lytoceras,$N=$ Nannolytoceras).

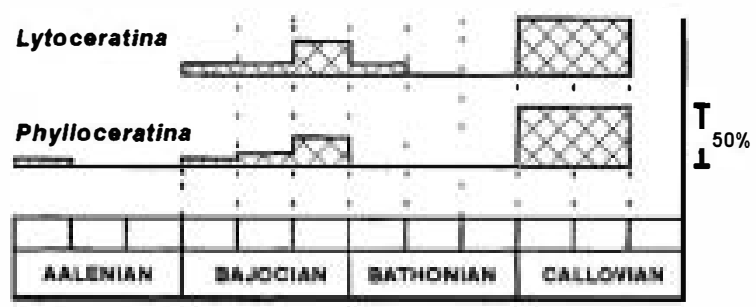

Fig. 3. Relative frequencies of Phylloceratina and Lytoceratina from the Iberian Chain in Middle Jurassic stages.

Upper Bathonian and Upper Callovian may result from the poor record of these stratigraphic intervals. However, the lack of record of these taxonomic groups in the Middle and Upper Aalenian and in the Middle Bathonian has been checked with ammonite collections of over one thousand specimens.

In the Upper Bajocian (Fig. 4), the following genera, in decreasing order of abundance, are recorded: Phylloceras s.1. (44.8\%), Adabofoloceras (20.7\%), Holcophylloceras (10.3\%), Calliphylloceras (6.9\%), Ptychophylloceras (6.9\%), Lytoceras (6.9\%) and Nannolytoceras (3.5\%). At the Lower-Middle Callovian boundary (Fig. 5) the recorded genera are: Calliphylloceras (30\%), Holcophylloceras (25\%), Phylloceras (22.5\%), Lytoceras (12.5\%) and Ptychophylloceras (10\%). At the generic level, Phylloceratina ammonoids show a lower diversity and higher equitability in the Callovian than in the Bajocian. Those forms showing constrictions or pseudoconstrictions 


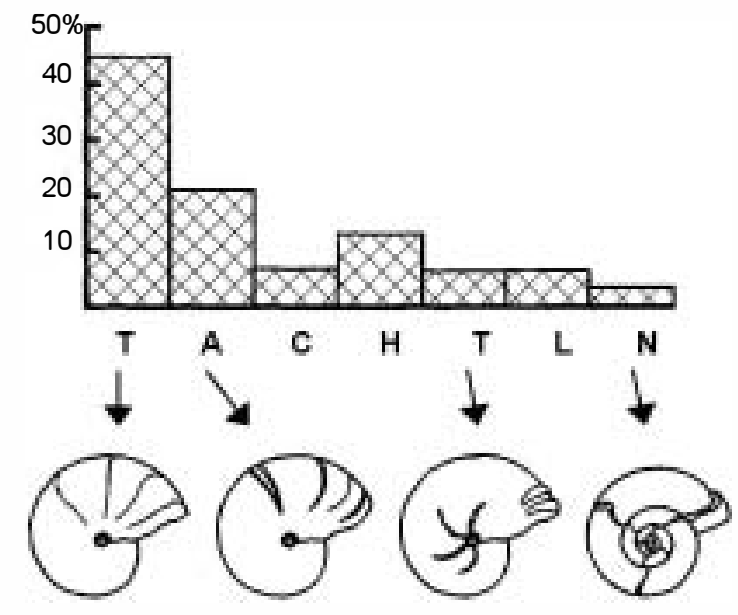

Fig. 4. Relative frequencies, at a generic level, of Phylloceratina and Lytoceratina from Upper Bajocian of the Iberian Chain.

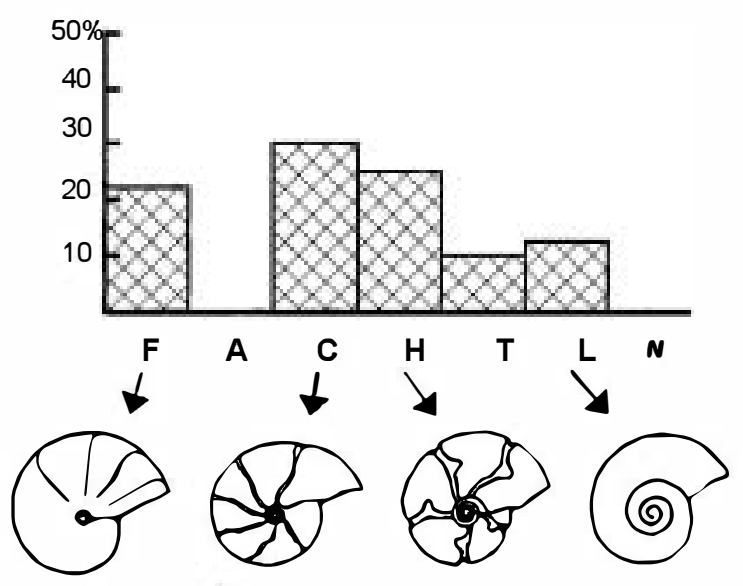

Fig. 5. Relative frequencies, at a generic level, of Phylloceratina and Lytoceratina from Lower to Middle Callovian of the Iberian Chain.

(Holcophylloceras and Calliphylloceras) are also more frequent at the Lower-Middle Callovian boundary than in the Upper Bajocian.

\section{Palaeoecological and biogeographical remarks on Phylloceratina and Lytoceratina}

Phylloceratina ammonoids have been often separated from other Ammonoidea by various criteria. Phylloceratina, or "liostraca" ammonoids, are characteristic of pelagic or oceanic environments. Conversely, "machyostraca" ammonoids are regarded as characteristic of neritic or shallow marine habitats (Arkell et al., 1957, p. L106). Supporting evidence for this interpretation is varied: functional morphology, evolutionary behaviour, palaeogeographical distribution and facies analysis.

The geometric shape of the shell, its microstructure, the greater thickness of the septa, the higher complexity of septal sutures and the lower relative diameter of the siphuncular tubes in Phylloceratina are significant differences in respect to other ammonoid groups, representing a greater ability to inhabit deeper water environments. In the case of adult ammonites it has been suggested that they could probably descend to some several hundred metres of depth. Resistance to implosion of ammonite shells would not exceed some 400-500 m depth. Only a few phylloceratids could reach greater depths than $1000 \mathrm{~m}$. Among them, consrricted forms do usually possess in addition septa and connecting rings that would have been less resistant to hydrostatic pressure, so they have been regarded as characteristic of relatively shallower water environments than non-constricted forms (Ward and Westermann, 1985; Hewitt and Westermann, 1987; Westermann, 1990, 1993).

Taking into account the Speciation and extinction rates of taxa and the mean time range of different genera of Ammonoidea, it seems that phylloceratids and lytoceratids were less affected by environmental changes, most especially eustatic oscillations, than other ammonoids during the Jurassic and Cretaceous. The longer specific and generic duration of Phylloceratina and Lytoceratina has also been interpreted as evidence for a more oceanic character of this taxonomic group (Ward and Signor, 1983).

Shells of Phylloceratina and Lytoceratina are abundant, both in number of specimens and species diversity, within sediments deposited in deep tethyan environments. They are, however, scarce or absent in epicontinental deposits. This restricted palaeogeographical distribution has been repeatedly used as an argument against long postmortem transport of ammonoid shells by nekroplanktonic drift (Hallam, 1975), as well as an 
evidence of palaeoecological control rather than of true provincialism (Geczy, 1967; Ziegler, 1967). Similarly, the presence of representatives of Phyllocerataceae (Phylloceras, Calliphylloceras, Holcophylloceras) in the boreal realm during the Middle Jurassic has been taken as evidence of this group being cosmopolitan (Imlay, 1962, 1964, 1973, 1982; Poulton, 1982, Poulton et al., 1992). On the other hand, some Toarcian and Aalenian Alocolytoceratinae are more common in some sedimentary basins in northwestern Europe and were probably adapted to shallower environments (Ziegler, 1981). Some specimens of Calliphylloceras invaded NW European areas during its greatest diversity, e.g. in the Toarcian and the Callovian (Galácz, 1980). Therefore, phylloceratids and lytoceratids were mainly, although not exclusively, Tethyan forms (Joly, 1976; Galácz, 1980, 1990; Enay, 1980; Tintant et al., 1982; Pavia, 1983; Cariou et al., 1985; Thierry, 1988a,b; Elmi, 1990; Cecca, 1992; Marchand, 1992).

A correlation between the proportion of phylloceratids and oceanic depth has been proposed for several sedimentary basins according to the lithoand biofacies. The obtained values range from less than $10 \%$ of Phylloceratina in some habitats interpreted as neritic until almost $100 \%$ of Phylloceratina in pelagic or deeper oceanic environments (Geczy, 1967, 1984). Phylloceratina shells would have been preferentially sedimented and preserved in deep-water deposits: 6th bathymetric stage $(300-500 \mathrm{~m})$ of Ziegler (1967) and the infrabathial zone of Scott (1940). However, although generally found in deep water sediments with scarce benthic remains, they may be also common (up to $>25 \%$ ) in benthos-rich sediments from the platform margin of epicontinental seas (Geyer, 1971). Biogeographical dispersal and ne kroplanktonic drift of shells (a case of taphonomic dispersal) must have been the main determining factors on the final distribution of Phylloceratina shells. The present distribution of shells would, therefore, reflect both their original and postmortem distribution (Fernández-López, 1983, 1985c; Tintant, 1984; Callomon, 1985; FernándezLópez and Mouterde, 1985; Westermann, 1990; Enay, 1993).

\section{Taphonomic remarks on Middle Jurassic Phylloceratina and Lytoceratina of the Iberian Chain}

Shells of Phylloceratina and Lytoceratina, as described above, display some other taphonomic and palaeoecological differences. Upper Bajocian specimens are usually small-sized $(D=10-30 \mathrm{~mm}$, excepting a single Lytoceras specimen, over $300 \mathrm{~mm}$ diameter). They correspond to juvenile or immature individuals, showing no traces of dwarfing or miniaturization (cf. Mignot, 1993; Mignot et al., 1993). They are either accumulated or else resedimented elements (sensu FernándezLópez, 1991) showing no signs of colonization by epizoans. They form ammonoid fossil assemblages characterized by their low specific diversity and equitability, composed of taphonic populations of the type 1 as categorized by Fernández-López (1985c, 1987, 1995). These associations are dominated by juvenile individuals and characterized by the occurrence of both dimorphs, macro- and microconch. This is the case of representatives of the generaSpiroceras, Bajocisphinctes, Lissoceras and Trimarginia, inhabiting the Iberian Basin at the end of the Niortense Biochron (FernándezLópez, 1985c, 1987) and representing eudemic organisms (sensu Callomon, 1985) during the Garantiana Biochron.

In contrast, Lower-Middle Callovian shells of Phylloceratina and Lytoceratina are usually larger in size $(D=50-300 \mathrm{~mm})$ and correspond to adult individuals or else incomplete, post-juvenile phragmocones. They are either resedimented or else reelaborated fossils (sensu Fernández-López, 1985a, 1991; Fernández-López and Gómez 1991; Fernández-López and Meléndez, 1994, p. 32) showing races of internal and/or external colonization on both sides of the shell. Among the colonizers, serpulids and bryozoans are most common. These specimens are commonly found in recorded associations showing higher taxonomic diversity and equitability at specific level than those from the Upper Bajocian. Ammonite associations are composed mostly by adult individuals and characterized by the absence of juvenile specimens (i.e. taphonic populations of type 3 or 2 in 
Fernández-López, 1985c, 1995; Fernández-López and Mouterde, 1994).

From a taphonomic point of view, it is also relevant to compare the values of relative frequency $(\mathrm{F})$ against those of the geographical persistence index $(\mathrm{P})$. The value of this index for a certain genus is expressed by the ratio between the number of localities of each substage where this genus is represented and the total number of localities where shells of Phylloceratina and Lytoceratina have been recorded. From the sixteen localities where these arnmonoids are reported in the Iberian Chain, ten are Upper Bajocian and eight Lower-Middle Callovian. In the Upper Bajocian sediments, representatives of the genus Phylloceras s.l. $\quad(\mathrm{F}=44.8 \%, \quad \mathrm{P}=70 \%)$ and Adabofoloceras $(\mathrm{F}=20.7 \%, \mathrm{P}=50 \%)$ are the most common and persistent (see Fig. 6). Representatives of the genus Calliphylloceras ( $F=$ $30 \%, \mathrm{P}=75 \%)$ and Holcophylloceras $(\mathrm{F}=25 \%, P=$ $75 \%$ ) are dominant, instead, at the Lower-Middle Callovian boundary. They show a lower relative frequency but higher geographical persistence than Upper Bajocian representatives of Phylloceras. Constricted phylloceratids (i.e. Holcophylloceras and Calliphylloceras) are the most common and geographically persistent at the Lower-Middle Callovian boundary, but they are very scarce in the Upper Bajocian.

Upper Bajocian and Lower-Middle Callovian rocks in the Iberian Basin also belong to two different facies, both characterized by the abundance of ammonites. Phylloceratina and

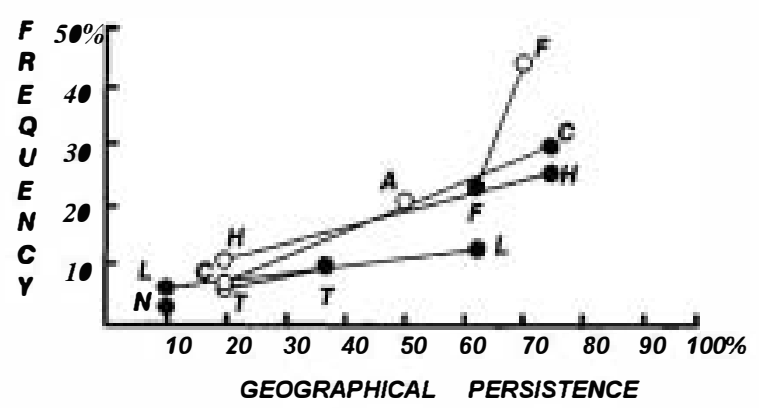

Fig. 6. Relative values of frequencies and geographical persistence, at a generic level, of Phylloceratina and Lytoceratina from Upper Bajocian (white dots) and from Lower to Middle Callovian (black dots).
Lytoceratina remains from the Upper Bajocian are associated with transgressive facies, deepening upwards sequences and expanded successions, developed under low turbulence conditions in relatively deep, subtidal environments (FernándezLópez, 1983, 1985c, 1987; Fernández-López and Gómez, 1991). Callovian remains of Phylloceratina and Lytoceratina, however, are associated with regressive facies, shallowing upwards sequences and condensed successions, formed under high turbulence conditions in shallow subtidal environments, locally emerged and submitted to subaerial alteration (cf. Geyer et al., 1974; Gómez, 1979; Gómez and Goy, 1979; Benke, 1981; Mensink and Mermann, 1984; FernándezLópez, 1985b; Wilde, 1988; Aurell, 1990; Aurell and Meléndez, 1990; Gómez and FernándezLópez, 1992, 1994; Aurell et al., 1995; FernándezLópez and Meléndez, 1995). This relative sea-level fall, however, in the Iberian Basin is not incompatible with a global rise of the sea level during de Early-Middle Callovian as proposed by several authors (Hallam, 1988; Haq et al., 1988).

\section{Interpretation of Phylloceratina and Lytoceratina in the Iberian Chain}

The presence of a fossil in a place does not mean that the producer organism lived there. Organisms may be recorded outside of their living area. Consequently, the concepts about the provenance of fossil remains may be distinguished from those about provenance of palaeobiological entities. The taphonomic concepts autochthonous/ allochthonous refer to remains recorded at the very place in which they were produced (autochthonous), or for those that have been ransported laterally after their production and are recorded now from a different place or region (allochthonous). Organisms may move by their own means or by passive transport outside of their breeding area (migratory species or passive biodispersal) but inside of their living area (Fig. 7). Therefore, demic species may be found in eudemic, miodemic or parademic conditions, depending on if they are inferred in their breeding area (eudemic; Callomon, 1985), in an area normally occupied but where 


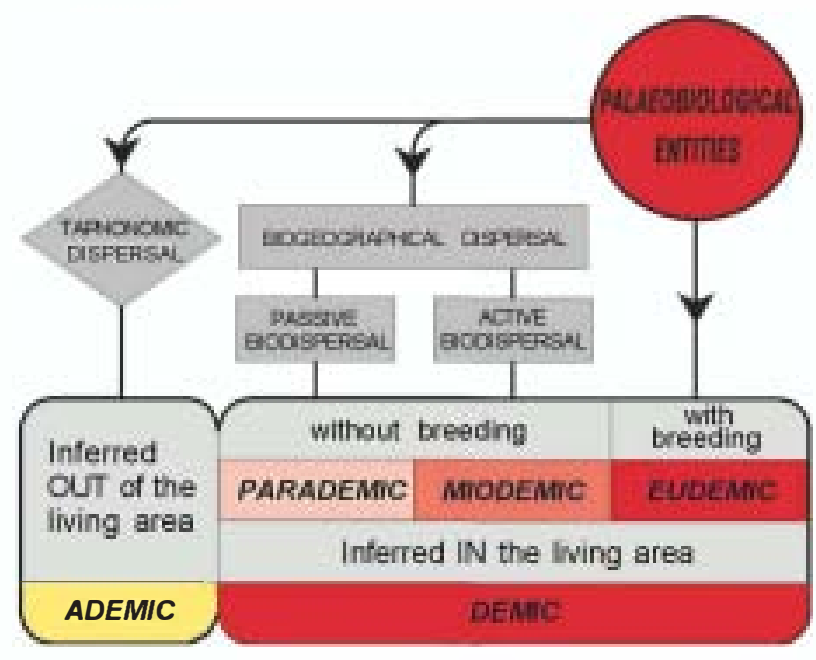

Fig. 7. Summary of palaeobiogeographical categories mentioned in text. The palaeobiological entities are demic when their remains are found in their living area. Conversely, they are ademic species or taxa when they are inferred outside of their living area. Demic species may be inferred in their breeding area (eudemic), in an area normally occupied but where they do not breed (miodemic), or in a living area occasionally reached by passive biodispersal (parademic).

they do not breed (miodemic), or in a living area occasionally reached by passive biodispersal (parademic; Fernández-Lỏpez, 1990, 1991; LópezMartínez and Fernández-Lőpez, 1993; FernándezLópez and Mouterde, 1994).

Callovian shells of Phylloceratina and Lytoceratina showing encrustation had to undergo nekroplanktonic drift during the biostratinomic phase and after the loss of the soft parts. Associations are characterized by the high proportion of large-sized shells, showing negative skew in the distribution of size-frequencies, and by the scarcity or even absence of juvenile individuals. These taphonomic features, associated with very shallow facies where reelaborated or reworked internal moulds are common, result from the higher capacity of nekroplanktonic drift in larger shells (cf Chamberlain et al., 1982; FernándezLópez, 1983, 1987, 1990). Phylloceratids displaying heavy pseudoconstrictions or constrictions (Calliphylloceras, Holcophylloceras), characteristic of shallower habitats, should have lower probability of flooding after death and higher probability of drift than the smooth forms of deeper habitats (Phylloceras). The relative sea-level fall during the Early-Middle Callovian transition, associated with an increase of the homogeneity of the Iberian Basin, favoured the arrival of shells by nekroplanktonic drift and increased the accumulaion of phylloceratid shells from other, more open marine or oceanic areas (i.e., these shells represent ademic individuals; Fig. 8).

In the case of Bajocian phylloceratids, the high proportion of small shells and the positive skew by the size-frequency distribution are taphonomic features disproving any processes of sorting by mechanical ransport (i.e. arrival of shells to the burial area by surface transport or by nekroplanktonic drift from distant areas). Among Bajocian phylloceratids, poorly ornamented or smooth forms (Phylloceras, Ptychophylloceras) are dominant and show higher geographical persistence than those showing heavy constrictions or pseudoconstrictions(Holcophylloceras, Calliphylloceras). It follows that some juvenile specimens of Phylloceras and Ptychophylloceras reached the Iberian Basin as immigrants. However, they did not breed or ontogenically develop in this basin, so they are miodemic organisms. During the Late Bajocian the Iberian Basin probably acted as a migration route for the phylloceratids and for some ammonite groups adapted to shallower environments (Fernandez-Lopez, 1985c), between the western Tethys areas and the proto-Atlantic or the Northwestern Europe epicontinental seas. However, the scarce specimens ofBajocian lytocerataceans recorded in the basin correspond to adult individuals and represent ademic (i.e., inferred out of the living area) or parademic organisms (transported within the living area).

Except for the Late Bajocian, this intracratonic, epicontinental migration route was not active during the rest of the Middle Jurassic. Stratigraphic intervals in which Ammonitina are scarce and Phylloceratina or Lytoceratina are rare to absent (Aalenian, Lower Bajocian, Bathonian and Upper Callovian) do not represent episodes of migration or taphonomic destruction but episodes of poor communication between the Iberian Basin and open marine, or oceanic environments. Shallow conditions in these sedimentary palaeoenvironments probably prevented both the ammo- 


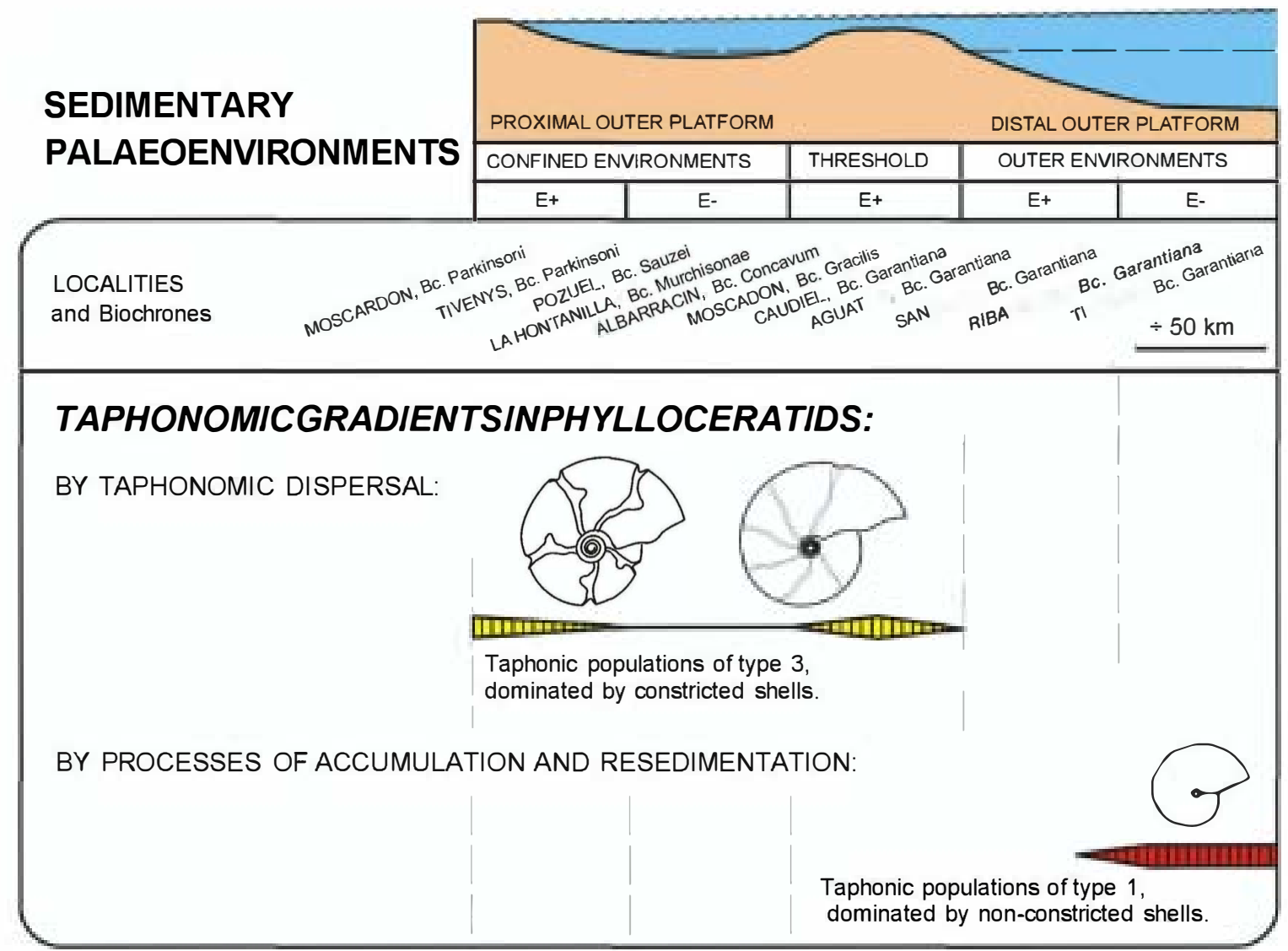

Fig. 8. Taphonomic gradients in Middle Jurassic Phylloceratina of the Iberian Basin, by taphonomic dispersal and by taphonomic accumulation and resedimentation.

nite migration along this route and the accumulation of drifted shells (Fig. 8).

The appearance of shells of Phylloceratina and Lytoceratina at the Upper Bajocian and at the Lower-Middle Callovian boundary in the Iberian Basin, associated with a greater abundance of Ammonitina, does not reflect two separate regional evolutionary events. These Middle Jurassic associations, containing the highest concentration of ammonoids (Ammonitina, Phylloceratina and Lytoceratina), resulted instead from environmental changes leading to the increase of the taphonomic potential of the basin. A higher amount of these shells was produced and imported into the basin during the Late Bajocian and Early/Middle Callovian than during any other interval in the Middle Jurassic. The biogeographical and taphonomic dispersal of ammonoids towards the Iberian
Basin took place under two opposite bathymetric conditions: ransgressive, deeper environments during the Late Bajocian (Garantiana Biochron) and regressive, shallow environments at the EarlyMiddle Callovian boundary. Accessibility and taphonomic dispersal of drifted elements was favoured as well during this second episode by the greater homogeneity of the sea-bottom.

As it has been shown for the Iberian Basin, the maximum relative sea-level fall favoured the taphonomic dispersal of adult phylloceratids and lytoceratids towards the epicontinental platforms increasing the abundance, richness and equitability of the recorded associations (Fig. 9). In contrast, maximum sea-level rise episodes favoured the biogeographical dispersal of juvenile phylloceratids towards the outer platforms leading to recorded associations with higher values of abundance and 

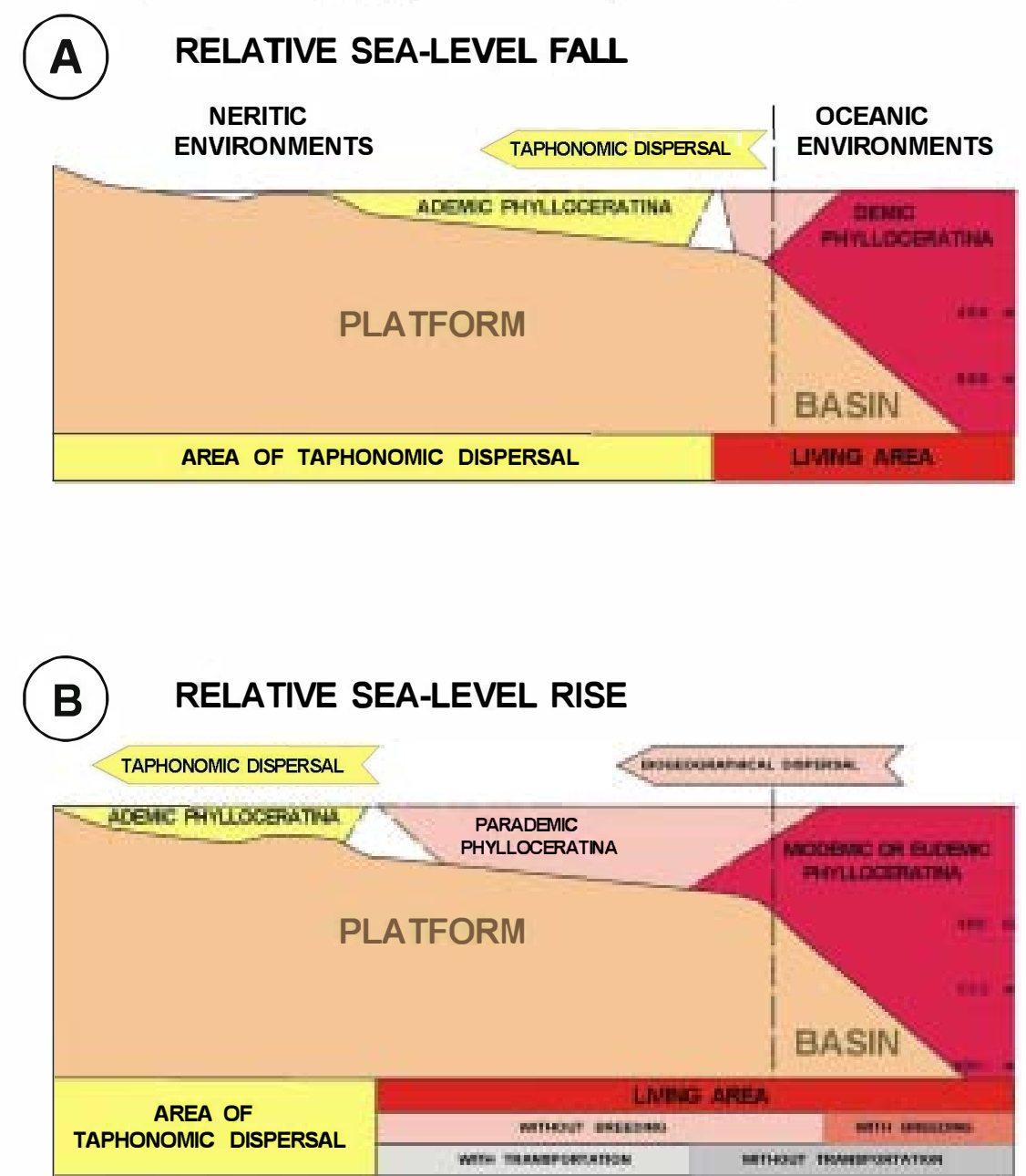

Fig. 9. Model of biogeographical and taphonomic dispersal for Middle Jurassic Phylloceratina, in relation to relative sea-level changes. Demic phylloceratids were mainly, although not exclusively, Tethyan forms living in oceanic environments. Eudemic phylloceratids inhabited basin areas, characterized by the occurrence of juvenile specimens. A. During episodes of relative sealevel fall, taphonomic dispersal produced the concentration ofphylloceratid shells in shallow platforms. These shells represent ademic species, characterized by the absence of juvenile specimens and dominated by adult individuals. B. During episodes of relative sea-level rise, active and passive biodispersal led to the occurrence in outer platforms of immigrant and transported phylloceratids, which respectively represent miodemic and parademic species. These miodemic species are dominated by juvenile individuals. In contrast, taphonomic dispersal produced the concentration of adult shells in shallow neritic environments, representing ademic species.

lower values of richness and equitability. The relative frequency and geographical persistence of phylloceratids can be used as an index to estimate the relative sea-level changes in epicontinental PeriTethyan basins. It should be noted, however, that the appearance and distribution of shells of Phylloceratina and Lytoceratina, and probably other Ammonoidea as well, were taphonomically and ecologically controlled by the regional particular bathymetric conditions in each basin.

\section{Conclusions}

In the Middle Jurassic, the taphonomic potential of the Iberian Basin with regard to ammonoid 
shells reached maximum values during two episodes of extreme bathymetric conditions: transgressive, deep environments during the Late Bajocian (Niortense Biozone, Baculata Biohorizon, and Garantiana Biozone), and very shallow, regressive conditions at the Early-Middle Callovian boundary.

The biogeographical dispersal of certain species and the arrival of immigrant ammonoids was favoured by a relative sea-level rise in the Late Bajocian, particularly during the Garantiana Biochron (Fernández-López, 1985; Hallam, 1988). Some juvenile specimens of Phylloceras and Adabofoloceras reached the Iberian Basin during this maximum depth interval. However, they did not find appropriate conditions for breeding nor for ontogenic development in this area. At the Early-Middle Callovian boundary, on the other hand, the relative sea-level fall associated with the higher homogeneity of the Iberian Basin increased the accessibility of phylloceratid shells by nekroplanktonic drift, particularly the shells of genera Calliphylloceras and Holcophylloceras, favouring the concentration of shells from open platform and oceanic areas. The scarce remains of adult Lytoceratids, recorded in both stratigraphic intervals probably represent ademic or parademic organisms.

The appearance and distribution of shells of Phylloceratina and Lytoceratina, and probably other Ammonoidea as well, in the Peri-Tethyan basins were taphonomically and ecologically conrolled by the regional changes of relative sea level.

\section{Acknowledgements}

This paper is a contribution to the project PB92-0011 (DGICYT) and has been partly financed by the Instituto de Estudios Turolenses (CSIC). Special thanks are due to Profs. R. Enay (University of Lyon), A. Hallam (University of Birmingham) and G.E.G. Westermann (McMaster University, Ontario) for their useful suggestions which helped much to improve the manuscript.

\section{References}

Arkell, W.J., Kummel, E. and Wright, C.W., 1957. Mesozoic Ammonoidea. In: R.C. Moore (Editor), Treatise on Invertebrate Paleontology, (L), Mollusca 4, Cephalopoda, Ammonoidea. Geol. Soc. Am., Univ. Kansas Press, Lawrence, KS, pp. L80-L437.

Aurell, M., 1990. El Jurásico superior en la Cordillera Iberica Central (provincias de Zaragoza y Teruel). Análisis de cuenca. Thesis. Dep. Geol. Serv. Publ. Univ. Zaragoza, pp. 1-389.

Aurell, M., Fernández-López, S. and Meléndez, G., 1995. The Middle-Upper Jurassic oolitic ironstone level in the Iberian Range (Spain). Eustatic implications. Geobios, in press.

Aurell, M. and Meléndez, G., 1990. Upper Jurassic of the Northeastern Iberian Chain (E. Spain); a synthesis. Seminar. Paleontol. Univ. Zaragoza (SEPAZ), 2: 5-33.

Bataller, J.R., 1922. El Jurásico de la Provincia de Tarragona. Trab. Mus. Nac. Cienc. Nat. (Geol.), 29: 5-113. Madrid.

Benke, K., 1981. Die Dogger/Malm-Wende in den NW-Keltiberischen Ketten (Spanien) und angrenzenden Gebieten-Sedimentologie, Stratigraphic und Paläogeographie. Facies, 4: 95-164.

Callomon, J.H., 1985. The evolution of the Jurassic ammonite family Cardioceratidae. Spec. Pap. Palaeontol., 33: 49-90.

Cariou, E., Contini, D., Dommergues, J.L., Enay, R., Geyssant, J.R., Mangold, C. and Thierry, J., 1985. Biogéographic des Ammonites et évolution structural de la Téthys au cours du Jurassique. Bull. Soc. Géol. Fr., 1: 679-697.

Cecca, F., 1992. Ammonite habitats in the Early Thitonian of Western Tethys. Lethaia, 25: 257-267.

Chamberlain, J.A., Ward, P.D. and Weaver, J.S., 1982. Postmortem ascent of Nautilus shells: implications for cephalopod paleobiogeography. Paleobiology, 7: 495-509.

Dereims, A., 1898. Recherches géologiques dans le Sud de l'Aragon (Ann. Hébert, 2). Thesis. Univ. Paris, pp. 1-199.

Elmi, S., 1985. Influence des haut-fonds sur la composition des peuplements et sur la dispersion des ammonites. In: Géodynamique des seuils et des hauts-fonds. Bull. Sect. Sci. Minist. Éduc. Natl., 9: 217-228.

Elmi, S., 1990. Réflexion sur les interactions entre révolution et l'adaptation des Ammonoides et la dynamique des aires sédimentaires. Cah. Univ. Cathol., Lyon, 4, pp. 153-159.

Enay, R., 1980. Paleobiogéographie et Ammonites jurassiques: rythmes fauniques et variations du niveau marin; voies d'échanges, migrations et domaines biogéographiques. Mém. Soc. Géol. Fr. h.s., 10: 261-281.

Enay, R., 1993. Les apports sud-téthysiens parmi les faunes jurassiques nord-ouest européennes: interpretation paleobiogéographique. C. R. Acad. Sci. Paris, 317: 115-121.

Fallot, P. and Blanchet, F., 1923. Observations sur la faune des terrains Jurassiques de la région de Cardó et de Tortosa Province de Tarragonne). Treb. Inst. Catal. Hist. Nat., 6 (1921-1922): 73-264.

Femández-López, S., 1980 Estudio bioestratigráfico (Ammonoidea) de materiales aalenienses en Ribarroja (Valencia). Estud. Geol., 35 (1979): 415-423. 
Femández-López, S., 1983. La biozona Garantiana (Bajociense, Jurásico medio) en la región de Tivenys-Sierra de Cardó (Tarragona). Estud. Geol., 38 (1982): 75-93.

Femández-López, S., 1985a. Criterios elementales de reelaboración tafonómica en ammonites de la Cordillera Ibérica. Acta Geol. Hisp., 19(1984): 105-116.

Femández-López, S., 1985b. Sequences sédimentaires et sequences taphonomiques. Strata, 2: 116-121.

Femández-López, S., 1985c. El Bajociense en la Cordillera Ibérica. Dep. Paleontol., Univ. Complutense, Madrid, pp. 1-850.

Femández-López, S., 1987. Necrocinesis y colonización posmortalenBajocisphinctes(Ammonoidea)delaCuencaIbérica. Implicaciones paleoecológicas y paleobatimétricas. Bol. Real Soc. Esp. Hist. Nat. (Geol.), 82: 151-184.

Femández-López, S., 1990. El significado de la autoctonía/ aloctonía tafonómica. In: S. Femández-López (Coodinator), Comunicaciones de la Reunión de Tafonomía y Fosilización. Dep. Paleontol., Univ. Madrid, pp. 115-124.

Femández-López, S., 1991. Taphonomic concepts for a theoretical biochronology. Rev. Esp. Paleontol., 6: 37-49.

Femández-López, S., 1995. Taphonomic et interprétation des paléoenvironnements. Geobios, M. S. 18: 137-154.

Femández-López, S. and Aurell, M., 1988. El Bajociense y Bathoniense de Ricla (Zaragoza). Características bioestratigráficas y sedimentológicas. Cienc. Tierra Geol., 11: 251-264.

Femández-López, S. and Gómez, J.J., 1990. Utilidad sedimentológica y estratigráfica de los fósiles reelaborados. In: S. Femández-López (Coord.), Comunicaciones de la Reunión de Tafonomía y Fosilización. Dep. Paleontol., Univ. Complutense, Madrid, pp. 125-144.

Femández-López, S. and Gómez, J.J., 1991. Condensación: significado y aplicaciones al análisis de cuencas. Estud. Geol., 47: 169-181.

Femández-López, S. and Meléndez, G., 1994. Abrasion surfaces on intemal moulds of ammonites as palaeobathymetric indicators. Palaeogeogr. Palaeoclimatol. Palaeoecol., 110: $29-42$.

Femández-López, S. and Meléndez, G., 1995. Taphonomic gradients in Middle Jurassic ammonites of the Iberian Range (Spain). Geobios, M. S. 18: 155-165.

Femández-López, S., Meléndez, G. and Suárez Vega, L.C., 1978. El Dogger y Malm en Moscardón (Teruel). In: Grupo Esp. Mesozoico, Guía de excursiones: Jurásico Cordillera Ibérica, 6, pp. 1-20.

Femández-López, S. and Mouterde, R., 1985. Le Toarcien, l'Aalénien et le Bajocien dans le secteur de Tivenys: nouvelles données biostratigraphiques. Strata, 2: 71-82.

Femández-López, S. and Mouterde, R., 1994. L'horizon á Gervillii (Bajocien inférieur) de Tendron (Cher, France). Taphonomic et populations d'Ammonites. Misc. Serv. Geol. Naz., 5: 117-159.

Galácz, A., 1980. Bajocian and Bathonian ammonites of Gyenespuszta Bakony Mts., Hungary. Geol. Hung., 39: $1-228$.

Galácz, A., 1990. New collection of successive ammonite faunas from the Bajocian of Mombasa (Kenya, East Africa). Mem. Descr. Carta Geol. Ital., 40: 199-204.

Geczy, B., 1967. Ammonoïdes jurassiques de Csemye, Montagne Bakony, Hongrie. Geol. Hung., 35: 1-414.

Geczy, B., 1984. Provincialism of Jurassic ammonites; examples from Hungarian faunas. Acta Geol. Hung., 27: 379-389.

Geyer, O.F., 1971. Zur paläobathymetrischen Zuverlässigkeit von Ammonoideen-Faunen-Spektren. Palaeogeogr. Palaeoclimatol. Palaeoecol., 10: 265-272.

Geyer, O.F., Behmel, H. and Hinkelbein, K., 1974. Die Grenzoolithe im Jura von Ostspanien. Neues Jahrb. Geol. Paläontol. Abh., 145: 17-57.

Gómez, J.J., 1979. El Jurásico superior en facies carbonatadas del sector levantino de la Cordillera Ibérica. Seminar. Estratigr. (Ser. Monogr.), 4: 1-683.

Gómez, J.J. and Femández-López, S., 1992. Secciones condensadas y máximos transgresivos. Una relación equívoca. Geogaceta, 11: 130-137.

Gómez, J.J. and Fernández-López, S., 1994. Condensation processes in shallow platforms. Sediment. Geol., 147-159.

Gómez, J.J. and Goy, A., 1979. Las unidades litoestratigráficas del Jurásico medio y superior en facies carbonatadas del Sector Levantino de la Cordillera Ibérica. Estud. Geol., 35: $569-598$

Hallam, A., 1975. Jurassic Environments. Cambridge Univ. Press, pp. 1-269.

Hallam, A., 1988. A reevaluation of Jurassic eustasy in the light of new data and the revised Exxon curve. In: C.K. Wilgus et al. (Editors), Sea-Level Changes: An Integrated Approach. SEPM Spec. Publ., 42: 261-273.

Haq, B.U., Hardenbol, J. and Vail, P.R., 1988. Mesozoic and Cenozoic chronostratigraphy and eustatic cycles. In: C.K. Wilgus et al. (Editors), Sea-level Changes: An Integrated Approach. SEPM Spec. Publ., 42: 71-108.

Haug, E., 1908-1911. Traité de Géologic Colin, Paris, pp. 1-2024.

Hewitt, R.A. and Westermann, G.E.G., 1987. Function of complexly fluted septa in ammonoid shells. II. Septal evolution and conclusions. Neues Jahrb. Geol. Paläontol. Abh., 174: 135-169.

Hinkelbein, K., 1975. Stratigraphic und Fazies im Mitteljura der zentralen Iberischen Ketten. Neues Jahrb. Geol. Paläontol. Abh., 145: 17-57.

Imlay, R.W., 1962. Late Bajocian Ammonites from the Cook Inlet Region, Alaska. Geol. Surv. Prof. Pap., 418-A: 1-14.

Imlay, R.W., 1964. Middle Bajocian ammonites from the Cook Inlet Region, Alaska. Geol. Surv. Prof. Pap., 418-B: 1-61.

Imlay, R.W., 1973. Middle Jurassic (Bajocian) ammonites from Eastem Oregon. Geol. Surv. Prof. Pap., 756: 1-1

Imlay, R.W., 1982. Late Bajocian ammonites from Southem Alaska. Geol. Surv. Prof. Pap., 1189: 1-19.

Joly, B., 1976. Les Phylloceratidae malgaches au Jurassique. Generalités sur les Phylloceratidae et quelques Juraphyllitidae. Doc. Lab. Géol. Fac. Sci. Lyon, 67: 1-471.

López-Martínez, N. and Femández-López, S., 1993. Geological biochronology and temporal correlations. GEOPREP Course Publ., 1: 1-69. 
Marchand, D., 1992. Ammonites et paléoprofondeur: les faits, les interprétations. Paleovox, 1: 51-68.

Marin, P. and Toulouse, D., 1972. Le Jurassique moyen et supérieur du Nord de la province de Teruel (Espagne): un exemple du passage Dogger-Malm dans la région d'Ariñooliete. Estud. Geol., 28: 111-118.

Meléndez, G., 1989. El Oxfordiense en el sector central de la Cordillera Ibérica (Provincias de Zaragoza y Teruel). Inst. Fernando el Católico, Inst. Estud. Turolenses, ZaragozaTeruel, pp. 1-418.

Meléndez, G., Aurell, M., Fontana, B. and Lardiés, D., 1990. El tránsito Dogger-Malm en el sector nororiental de la Cordillera Ibérica: análisis tafonómico y reconstrucción paleogeográfica. In: S. Fernández-López (Coodinator), Comunicaciones de la Reunión de Tafonomía y Fosilización. Dep. Paleontol., Univ. Madrid, pp. 221-229.

Mensink, H., 1966. Stratigraphie und Paläogeographie des marinen Jura in den nordwestlichen Iberischen Ketten (Spanien). Beih. Geol. Jahrb., 44: 55-102.

Mensink, H. and Mertmann, D., 1984. RegressionenTransgressionen während des unter-Callovium in den nordwestlichen Keltiberischen Ketten, Spanien. Z. Dtsch. Geol. Ges., 135: 37-44.

Mignot, Y., 1993. Un problème de paléobiologie chez les Ammonoïdes (Cephalopoda): croissance et miniaturisation en liaison avec les environnements. Doc. Lab. Géol. Lyon, 124: 1-113.

Mignot, Y., Elmi, S. and Dommergues, J.-L., 1993. Croissance et miniaturisation de quelques Hildoceras (Cephalopoda) en liaison avec des environnements contraignants de la Téthys toarcienne. Geobios, M.S., 15: 305-312.

Pavia, G., 1983. Il genere Ptychophylloceras Spath, 1927 (Ammonoidea, Phyllocerataceae) nel Baiociano sudeuropeo. Atti Accad. Naz. Lincei, 17: 1-31.

Poulton, T.P., 1982. Paleogeographic and tectonic implications of the Lower and Middle Jurassic facies patterns in northern Yukon Territory and adjacent Northwest Territories. In: A.F. Embry and H.R. Balkwill (Editors), Arctic Geology and Geophysics. Can. Soc. Pet. Geol. Mem., 8: 13-27.

Poulton, T.P., Detterman, R.L., Hall, R.L., Jones, D.L., Peterson, J.A., Smith, P., Taylor, D.G., Tipper, H.W. and Westermann, G.E.G., 1992. Western Canada and United States. In: G.E.G. Westermann (Editor), The Jurassic of the Circum-Pacific. Cambridge Univ. Press, pp. 29-92.

Riba Arderiu, O., 1959. Estudio geológico de la Sierra de Albarracín. Monogr. Inst. Lucas Mallada, 16: 1-283.

Scott, G., 1940. Paleoecological factors controlling distribution and mode of life of Cretaceous ammonoids in Texas. J. Paleontol., 14: 1164-1203.

Sequeiros, L., 1987. Indices de semejanza faunística en
Paleogeografia: Aplicación al Calloviense inferior de España. Paleontol. Evol., 20 (1986): 311-315.

Sequeiros, L. and Cariou, E., 1985. Síntesis bioestratigráfica del Calloviense de Ricla (Zaragoza, Cordillera Ibérica). Estud. Geol., 40 (1984): 411-419.

Sequeiros, L., Cariou, E. and Meléndez, G., 1985. Algunos ammonoideos del Calloviense superior de Aguilón (Zaragoza, Cordillera Ibérica). Estud. Geol., 40 (1984): 399-410.

Thierry, J., 1988a. Provincialisme et/ou écologie des ammonites du Callovien en France. In: J. Wiedmann and J. Kullmann (Editors), Cephalopods Present and Past. Schweizerbart, Stuttgart, pp. 387-402.

Thierry, J., 1988b. Structure and palaeogeography of the Westem Tethys during the Jurassic: tests based on ammonite palaeobiogeography. In: M.G. , Audley-Charles and A. Hallam (Editors), Gondwana and Tethys. Geol. Soc. Spec. Publ., 37: 225-234.

Thierry, J. and Wilde, S., 1990. Bathonian-Callovian (Middle Jurassic) ammonite faunas of the North-West Iberian Ranges: biostratigraphy and palaeobiogeography. Cuad. Geol. Ibér., 14: 143-156.

Tintant, H., 1984. Autochtonie ou allochtonie chez les Céphalopodes. Mém. Géol. Univ. Dijon, 7 (1982): 257-271.

Tintant, H., Marchand, D. and Mouterde, R., 1982. Relations entre les milieux marins et l'évolution des Ammonoïdes: les radiations adaptatives du Lias. Bull. Soc. Géol. Fr., 5-6: 951-961.

Ward, P.D. and Signor III, P.W., 1983. Evolutionary tempo in Jurassic and Cretaceous ammonites. Paleobiology, 9: 183-198.

Ward, P.D. and Westermann, G.E.G., 1985. Cephalopod Paleoecology. Univ. Tenn. Stud. Geol., 13: 215-229.

Westermann, G., 1955. Biostratigraphische Untersuchungen im Jura südlich der Sierra de la Demanda (Nord Spanien). Geol. Jahrb., 70: 519-534.

Westermann, G., 1990. New developments in ecology of Jurassic-Cretaceous ammonoids. In: G. Pallini et al. (Editors), Fossili, Evoluzione, Ambiente. Atti 2nd Conv. Pergola, pp. 459-478.

Westermann, G., 1993. Hydrostatics and hydrodynamics of cephalopod shells: form, structure and function. An. Acad. Cienc. Ex. Fís. Nat. Buenos Aires, 45: 183-204.

Wilde, S., 1988. Das Bathonium und Callovium der nordwestiberischen Ketten (Jura, Spanien). Bochumer Geol. Geotech. Arb., 31: 1-217

Ziegler, B., 1967. Ammoniten-Ökologie am Beispiel des Oberjura. Geol. Rundsch., 56: 439-464.

Ziegler, B., 1981. Ammonoid biostratigraphy and provincialism:Jurassic_-Old World. In: M.R. House and J.R. Senior (Editors), 1980), The Ammonoidea. Academic Press, London, pp. 433-457. 